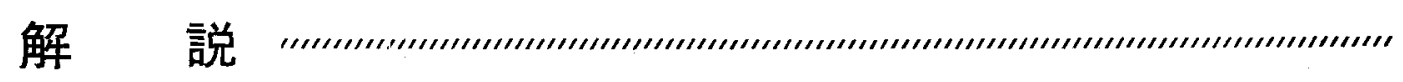

\title{
修飾電極の概要亡選択的電解合成への応用
}

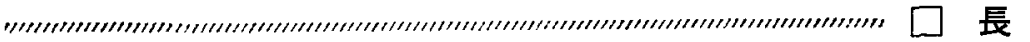

哲 郎*

Tetsuro OSA
1 はじめに

電極表面は通常電極材質そのものの化学組成と同一で なく,空気ないしは電解液化接すると,それらとの化学平 衡状態にある，たとえば，金属電極，炭素電極の表面は 酸化ふん囲気下においては酸化物を:生成しており，もと もとの電極材質とは異なっている，害際の電極表面はこ のような状態にあるが, 機能性物質を積極的に電気伝導 性物質の表面に化学結合ないしは強吸着させ, 電子伝達 の場に供したものを修飾電極 (modified electrode, derivatized electrode, immobilized electrode), あるいはさ らに限定して化学修飾 電極 (chemically modified electrode, chemically derivatized electrode, chemically immobilized electrode) と呼称してよいであろう.

文献上の後者の最初の使用は 1975 年 Miller らによ る研究に始まる゙、。なわち，彼らはグラファイト電極

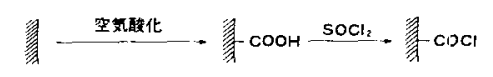

グラファイト
(S) $-\mathrm{PhCH}_{2} \mathrm{CHNH}_{2}$
$\mathrm{COOCH}_{3}$

を $160^{\circ} \mathrm{C}, 36$ 時間空気酸化してカルボキシル基を導入 し,ついで塩化チオニルで酸クロリドとなし， $(S)-(-)$ フェニルアラニンメチルエステルをアミド結合により固 定したもので，この不斉修飾電極 (1)を用い，4-アセチ ルピリジン（2）およびフェニルグりオキシル酸エチル (4) の不斉還元が行なわれた。

このように, 最初の論文が機能性化合物を化学結合に より修飾した電極であったため，また，引き続いて化学 結合を用いた電極に関する研究が数多く発表されたため もあって,著者らは化学修飾電極と淤“電極表面をケイ素 化剤を経由し，あるいは直接に通常つ有機合成反応を利 用して，特定の機能を有する分子を電極表面に共有結合 的に固定したもの”として紹介した 2. しかし，この方法 では機能性物質を任意の表面密度で北学修飾することは 現技術では困難であり，高分子被覆電極 (polymer coated

\footnotetext{
* 東北大学薬学部（于980 仙台市䐠巻宗青葉）
}

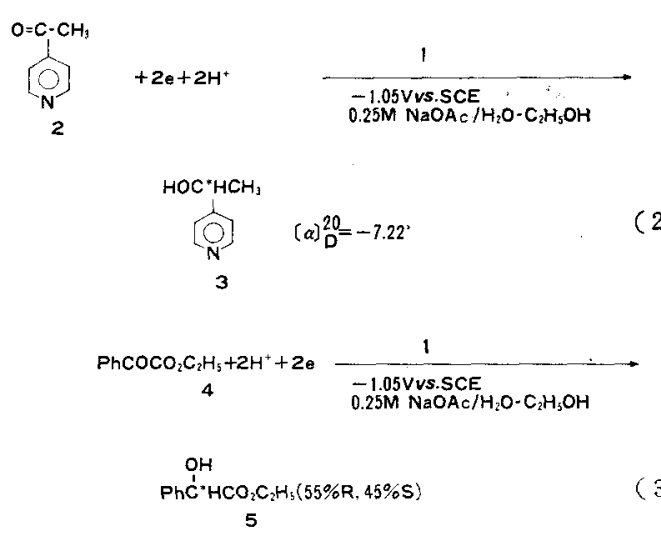

electrode $)^{* 1}$ や，さらに機能性物質を強吸着したグラフ アイト電極の研究も盛んになって抢り, 現在はこれらす ベてを含むような広い定義の方が妥当である。

以上の観点加らは, 本特集の半導体電極, 工業用電極 のかなりの部分が化学修飾電極の範畴に含まれることに なるが，なる心く重複を避けるためにそれぞれの電極の 修飾法, 電極表面特性, 利用を中心とした各諭が，それ ぞれの分野の研究者により執筆されている。本稿では著 者らの研究を中心として, 電極の化学修飾法, 化学修飾 電極表面のキャラクタリゼーション, 電極反応機構, 選 択的電解合成一の応用学簡単に紹介し,さらに化学修飾 電極の機能または用途, 問題点なども言及する.

\section{2 電極の化学修飾法}

電極の表面に化学結合しうる官能基を導入できれば， 通常の機能性物質を化学修飾できる。

グラフォイト,グラッシーカーボン，パイロリティッ クグラファイトの炭素系電極の化学修飾法を図 1 亿示 す. 空気酸化 ${ }^{13}$, 試薬酸化 ${ }^{3)}$, または酸素プラズマ酸化 ${ }^{43}$ などによる含酸素基の導入反応，混酸によるニトロ化と その還元によるアミノ基の導入反応 ${ }^{57}$, 真空加熱 ${ }^{67}$, 機 械的摩擦》またはアルジンプラズマ゚゙によって含酸素基

*1 高分子錯体修飾電極，修飾電極の応用の項では高分子惍飾 電極の用語ぶ使用されている。 


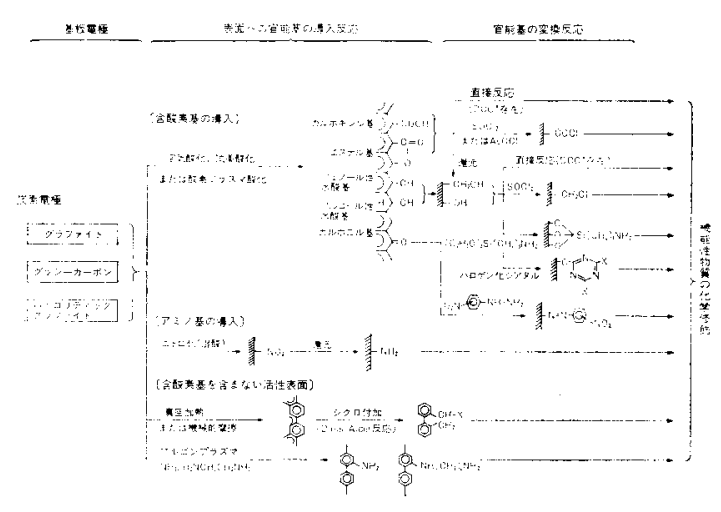

図 1 炭素系電極の化学修飾法

を含まない活性な $\pi$ 電子系炭素表面を生成させシク口付 加の反応などによる官能基の導入反応をまず行なら．グ ラファイト層に平行な面 (basal 面) は酸素と反心せ ず9，層に垂直な面 (edge 面) のみ反応するとの報告 ${ }^{10)}$ むあり，反応性に差があるものと考えられるが，グラッ シーカーボンについては面に関係なく官能基を導入でき る.引き続き必要に応じて官能基の変換反応を行ない, 最後に種々の機能性を有する物質を化学修飾する。著者 らは，アミド，エステル，カルボニル，炭素崖素，岸 素-窒素の各結合の生成に成功している.

金属酸化物半導体電極と金属電極の化学修飾法を図 2 に示す ${ }^{2,11)}$.これらの電極では表面のヒドロキシル基を 利用するので，金属電極の場合には，まず表面の酸化処 理が行なわれる，ヒドロキシル基の表面密度を大きくす るためには表面酸化物の酸またはアルカリ処理が効果的 である. $\mathrm{SnO}_{2}{ }^{12,13)}, \mathrm{TiO}_{2}{ }^{14 \sim 16)}, \mathrm{RuO}_{2}(\mathrm{DSA})^{15,17 \sim 19)}, \mathrm{Pt} /$ $\mathrm{PtO}^{15,17,19,20)}, \mathrm{Au} / \mathrm{Au}$ (酸化物) ${ }^{21,22)}, \mathrm{Si} / \mathrm{Si}$ (酸化物) ${ }^{23,24)}$,

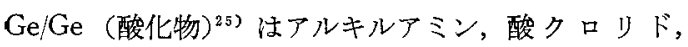
ピリジンなどを含む有機シラン化合物とシロキサンの結 合を介して官能基が導入できる．電極と機能性物質との 結合距離を短かくするためには, 表面ヒドロキシル基と 機能性物質の直接的なエステルまたはエーテル結合の生 成 ${ }^{11}$ が好ましい，たとえば，半導体表面への色素の化学 結合を利用した光電流発生の光量子収率はこの方法によ

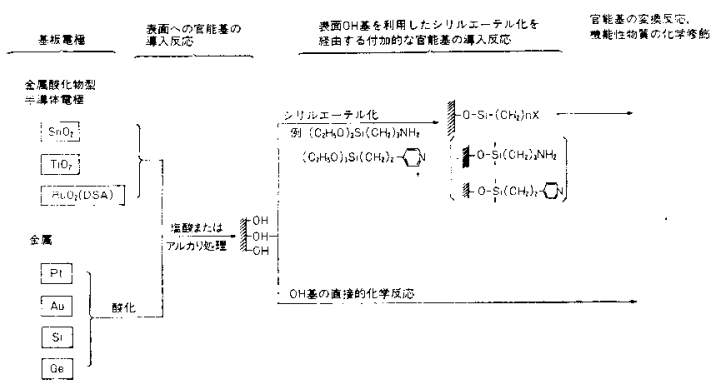

図 2 金属酸化物および金属の各電極の化学修飾法
って向上できる 26,27$)$.

かくして得られた化学修飾電極の試薬や電極反応に対 する安定性は，用途閒発のための重要な因子であるが， また十分な研究が行なるれるには至っていない，後述す るよらに電気化学的版起状態の保持時間に依存するのは もちろんであるが，通常の化学反応に対する安定性と類 似の関倸が予想され，エステル，カルボニルくアミドく エーテル<炭素-窒素〜炭素-炭素の序列を考えてよいで あろら

前述の化学結合法古理想的に行なえば，電極表面に機 能性物質の単分子層腠を形成できることになるが，実際 には基板電極表面の賏能基の密度が低かったり，機能性 物質上の反応が十分進行しなかったりして, 十分密な単 分子層の形成は容易てない：この問題の解決には 1 で触 れたように，高分子被覆電極によるのが效果的であると 考えられ，大別して次の 4 方法で製造されている.

(1) 吸着法：高分子溶液からの吸着 ${ }^{28 ~ 31), ~ ス ヒ ゚ ン コ ~}$ 一ティング法" ${ }^{3 ! 2}$, 電解析出法 ${ }^{33 \sim 35)}$

(2) 重合法 ${ }^{36)}$

(3) プラズマ放䈏重合 ${ }^{7,37)}$

（4）重合物との其有結合 ${ }^{35,38,393}$

これらの諸法で電氛化学的に安定な表面が生成でき, しかも，電子移動比対し多少の妨害があるとしても電極 材質の電気的活性は通常損なわれず，また高分子膜の化 学的状態も安定に保たれる。

鉄フタロシアニンを濃硫酸に溶解しグラファイトに吸 着させた電極は, 酸点の電気化学的還元に活性があり, かつ吸着した鉄フタロシアニンは安定に電極上に存在す ることが報告されていたが40)，乙の後，機能性物質を安 定に吸着させた電極の研究も数多い.たとえば, ヨウ素イ オンは白金にヨウ素としてきわわて強く吸着する ${ }^{29,41)}$. 芳香族化合物は一般にグラファイト電極に強く吸着し， 9,10ーフェナントレキノン ${ }^{42,433}$ ，鉄テトラフェニルポル フィリン ${ }^{422}$ の例など枋ある。

\section{3 化学修飾電㥛表面のキャラクタリゼー ション}

化学修飾された電極表面に対しては，機能性物質の表 面密度または被覆率の定量のほかに, 電極面やその隣接 分子との構造的, 空闑的, 動的関係のようなミクロな環 境を明らかにする必要がある。この関係の測定法として は次のものがあげられる.

(1) 電子分光法

a. ESCA, Auger, IETS による表面化学種の同定と 定量

b. イオンエッチングを併用した表面深さ方向の組成 変化の測定

(2) 分光学的方游 
c. 高感度紫外可視分光法に上万表面化学種の量の決 定 (色素分子など)

d. FTIR による表面化学種ないしは結合種の決定

e. 共鳴ラマン分光法による表面化学種の配向の情報

f. 光音響分光法に上る表面化学種の確認

g. 分光増感電流スペクトルによる表面化学種の確認 (色素修飾半導体の場合)

h. 電気化学発光スペクトルによる表面化学種の確認 （電気化学発光物質の化学修飾の場合）

(3) 電気化学的方法

i. ボルタンメトリーによる表酗電気化学活性種の定 性と定量

j. 電気二重層容量変化の測定による化学修飾層の情 報

k. 表面電気伝導度の測定による化学修飾層の厚さと 官能基量の情報

ます，化学結合電極の場合化は，吸着ではなく化学結 合の確認が必要である。これに対してはdないしe 法が 有効であ万う．特に d 法は有勃であるが，吸光係数が小 さいため成功例はない，a 法を朋いても $\mathrm{C}, \mathrm{O}, \mathrm{N}$ の シグナルのケミカルシフトは化学結合に対する知見を与 える.

次に化学修飾種の表面被覆量の問題がある. 前出の多 くの方法は知見を与えはするが，定量的解析化はなかな か至らない，電極材質の含有元素と異なる元素, とくに 金属が化学修飾種に含まれる場合仙、法は有効である が，著者らの測定では $\mathrm{C} ， \mathrm{O}, \mathrm{N}$ の定量はほとんど不可 能であった．現在はｉ法が最も簡假な測定法となってい る. 通常，化学修飾種の被覆量はサイクリックボルタン メトリー $(\mathrm{CV})$ の測定加ら $0.8 \sim 10 \times 10^{-10} \mathrm{~mol} \mathrm{~cm}^{-2}$ と 得られ，Langmuir 型単分子配向として計算した值より 小さいか，またはほぼ等しい值となる。一般に被覆率は 熱運動の自由度や界面の流動性から考えて維密な化学修 飾法を施しても，ゆるい単分子層の表面構造をとるもの と推定され，図３亿示すようないわゆる “floppy 分子”

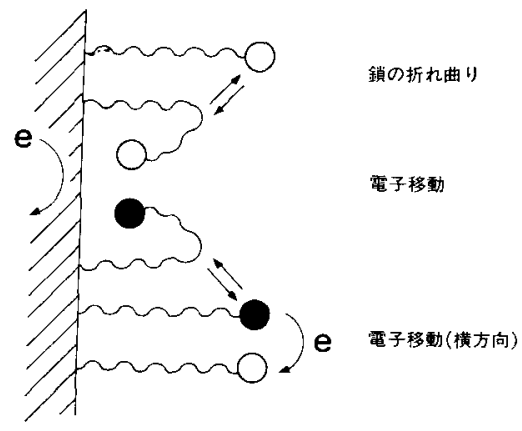

図 3 化学修飾単分子層上でゆ電子移動反応 のモデル

O:酸化種, ・ : 這元種
のモデルが妥当と考えられている ${ }^{14,15)}$. シリルエーテル 結合で表面を化学修飾した場合にはシロキサンポリマー を生成しやすく，3〜6 層またはそれ以上の厚い膜とな $ろ^{21,44)}$. 著者らは Auger を用いグラッシーカーボン酸 化表面のアルゴンスパッタリングを行なったが，表面か ら $10 \AA$ 以内の厚さにのみ含酸素基は存在し, また表面 での含酸素基の分布むかなり均一であることがわかって いる(5).

\section{4 化学修飾物の電極反応挙動}

溶液中に存在するレドックス種の電位と，電極表面に 化学結合されたレドックス種の電位は非常に近いことが 報告されており ${ }^{19)}$, 形式上のレドックス電位 $E^{\circ \prime}$ は基板 電極の種類や電極上への非可逆的固定法には鋭敏でない 場合が多い.レドックス種の表面濃度は，10 の の長さ の鎖で吊るされている場合 $2 \mathrm{~mol} \mathrm{dm}^{-3}$ 程度に相当する ので，界面の溶媒濃度を減少し，活量に本質的な影響を 与えるはずであるが，上述の結果は化学修飾レドックス 種の酸化体と還元体の自由エネルギー変化は末修飾のそ れとあまり変らないことになる．

表面活量は CV ピークの線幅 $\left(E_{\mathrm{fwhm}}\right)$ に現われ

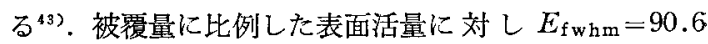
$\mathrm{mV}$ であるが ${ }^{46)}$, “反発”活量パラメーターとの指数的 関係注広幅のピークを予想させる ${ }^{43}$. いままでの測定值 は長鎖アルキルを有する高被覆量のフェロセンの $85 \mathrm{mV}$ を除き38 $90.6 \mathrm{mV}$ 以上である.ただし，表面構造の不 均一性もピーク幅を広げるので17,47)， $E_{\mathrm{fwhm}}$ の值から の議論も単純でない.

電極に不可逆的に固定されたレドックス種のピーク電 位およびピーク電流に関して CV，微分パルスボルタン メトリーで理論的誘導 ${ }^{(3)}$, 実測值との比較 ${ }^{17}$ が行なわれ ている. 表面レドックス種の酸化体の割合 $\mathrm{f}$ が 0.5 であ ると酸化ピーク電位 $E_{\mathrm{a}}$ と還元ピーク電位 $E_{\mathrm{c}}$ は等し くなり，表面の酸化体と還元体の相互作用を表わす非理 想性パラメー夕 $r\left(\gamma_{\mathrm{O}}=\gamma_{\mathrm{R}}\right)$ は $-1 \times 10^{9} \mathrm{~cm}^{2} \mathrm{~mol}^{-1}$ のよ らな負のきわめて大きな值となる ${ }^{38,433}$ 。この值はある種 の非安定化プロセスのあることを推定させる。一方ては 全表面濃度 $\Gamma$ の減少により減少するが， $r \times \Gamma=$ 一定の 関係も見いだされ，前記理論との矛盾が示され， $E^{\prime \prime} の$ 時間によるシフトのパラメーターの導入も必要との指摘 もある゙8)

レドックス対が鎖により電極表面に吊り下げられてい る場合は, 平均の電子移動距離注明らかでないとしても， レドックス種は吊り下げられていない場合より電導性表 面から遠く離れているものと予想される。しかし図 3 の ような “floppy 分子”モデルを考えると，鎖の折れ曲り によりレドックス対は電尊性表面に近づき容易に電子移 動を行なったり，折れ曲っていなく上も横方向での電子 
移動を介して行ならことができるだろら ${ }^{15)}$. 鎖の折れ曲 がりのエネルギー障壁が溶液中の分子の㹡散障壁に見合 うものであれば, $D=\sim 10^{6} \mathrm{~cm}^{2} \mathrm{~s}^{-1}$ と仮定すると衝突頻 度 (collision frequency) は $10^{8} \sim 10^{7} \mathrm{~s}^{-1}$ となり，予想 值よりはるかに小さいが48)，物質輸送因子は非常に早 く，早い走引速度の CV においても制約されない，

多層またはポリマー中のレドックス対の荷電の輸送は 隣接する局在レドックス種間の電子跳躍に上るであるら 加ら，その電子輸送注遅く，かつ複雑となるものと推定 され，CV 図はしばしば鋭くなる7,21,35,44).

レドックス種を強吸着した電極の場合には，化学修飾 の場合に比べてレドックス種を電極表面により近ゔける ことができる、したがってパイロリティックグラファイ トへの $\pi$ 系分子の吸着の場合の衝突頻度は約 $6 \times 10^{2} \mathrm{~s}^{-1}$ となり ${ }^{42)}$ ，電子移動速度は測定できない活ど速い(4)。

化学修飾された電気化学的励起種の安定性は，電極之 の化学結合には依らず,この活性種の反応性, 特に活性状 態で存在する時間に依存するとの報告むある ${ }^{18,20,49}$. 化 学修飾単分子膜から生成したニトロ芳香族ラジカルアニ

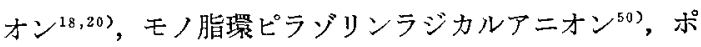
リピリジン $\operatorname{Ru}(I)$ 錯体 ${ }^{5 t)}$ の安定性は, 化学修飾してい ないこれらの分子や高分子多層膜に存在するこれらの分

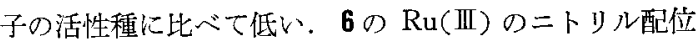

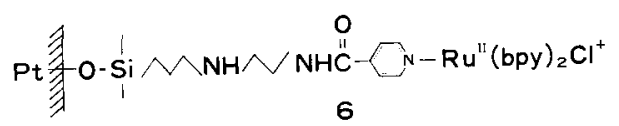

子置換反応の速度は化学修飾した場合は増大寸るが51), $\mathrm{Ru}(\mathrm{III})-$ EDTA 錯体のそれ注化学修飾した場合約 1000 倍低下する ${ }^{2 n)}$.

1-アミノーおよび 2-アミノ-9,10-アントラキノンをグ ラファイト電極にアミド結合で修飾して CV 測定を行 ならと，1-アミノ異性体のみピークが観測される ${ }^{53)}$. 電 極に対し芳香族が平行に配向すると電子移動は最大とな るはずで，1ーアミノ異性体は電極に結合しながらこの平 行配向をとるが，2-アミ>異性体の場合注配向が異なる ためか電子移動性察されなかった。著者らもグラッシ

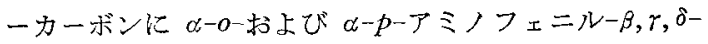
トリフェニルポルフィリン鉄をアミド結合で修飾したと ころ, 酸素還元の電気化学的触媒電流前者の方が後者 より大きかった，その理由としてのーアミノ体はポルフ

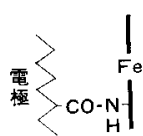

7

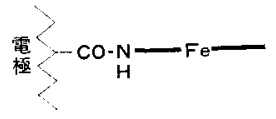

8
イリン面が電極に対し平行配向 7 するのに対し, $p$-アミ ノ体は垂直配向 8 するためと予想している
溶液中に存在する分子の電子移動反忘に対する化学修 飾電極の效果も重要である．シロキサン結合 ${ }^{12,15)}$ ，化学 吸着 ${ }^{42)}$ 単分子層で汇多くの場合, 溶液分子の電子移動 速度を低下させる. しかし，多くの電気化学的触媒反応 をこの表面で行なうことができる.ジヒドロニコチンア ミドアデニンニリン酸 $(\mathrm{HADH})$ の上うな大きな分子の 電極との電子移動反応は mediator を溶液中に共存させ ないと進行しないが，キノンーヒドロキノンのレドック ス対となる誘導体を伦学結合させると，これが mediator の作用をして NADH を NAD に酸化することができ る55など，特徴ある効果を示すことがある。

\section{5 化学修飾電極に期待できる機能}

以上の上うに，化学修飾電極に预ける電極反态の解明 に注，分子レベルでの考察や分子レベルでのデザインが 必要となり，これらは必然的に化学修飾電極の用途開発 につながる。

図 4 亿は，これまで著者らが達成した化学修飾電極に よる種々の機能性電極の概要を示した、いずれもまだ基 礎研究の段階で, 実用化には至っていないが, 発展の可 能性を秘めている．分子のもつ機能は化合物の種類が豊 富であるように，決こて図 4 亿示したような機能をけに 溜まらない，すな斺ち，今後化学修飾電極の種類が増 加するに従って，現任で法測もつかないような機能を 有する電極の出現が澌待できよう。

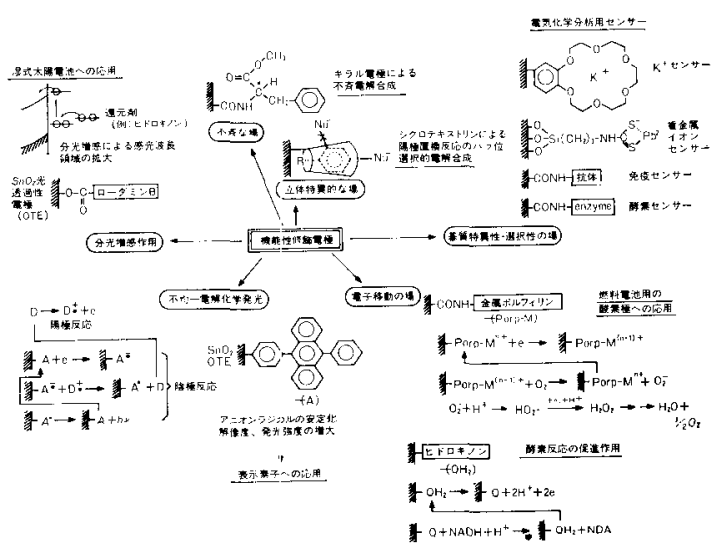

図 4 化学修飾電極の機能または用途

図4に法してないが，電気化学的な酸化・還元反応 によりその一方もしくは両方が着色するエレクトロクロ ミズムの現象を利用した，エレクトロクロミック表示素 子への利用が研究されている。この紹介はディスプレー 用修飾電極の項でなされる。

\section{6 化学修飾電㥛の選択的電解合成への忘用}

図 4 亿示した化学修飾電極の機能または用途のらち, 
本節では電解合成への応用に関してのみ簡単に紹介す る.

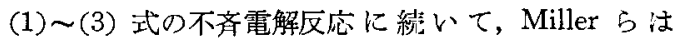
(2) 式枋よび(4) の反応を, basal 解と edge 面が露出し

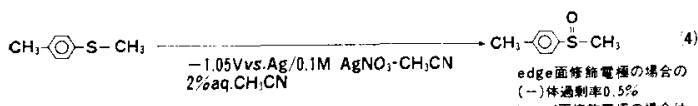

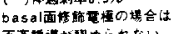

た規則性の大きいパイロリティックグラファイトを (1) 式に従って化学修飾したキラル電極で行ない，不斉誘導 にはグラファイトの edge 面が有胶であることを報告し だ2,10)。さらに(5) 式により(一)-カンファン酸で修

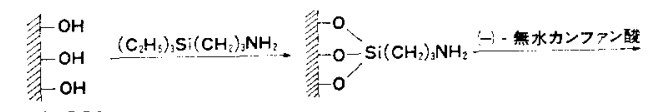

$$
\begin{aligned}
& \mathrm{SnO}_{2}, \mathrm{DSA}
\end{aligned}
$$

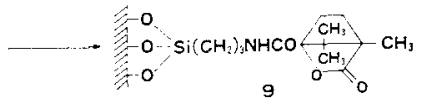

飾したシリルエーテル化 $\mathrm{SnO}_{2}$ および DSA 電極によ り（4）式の反応を行ない，(一) 鏡像異性体過剩率 0.3 〜 1.4\% を得ている ${ }^{56)}$.

一方, Horner と Brich ${ }^{57)}$ はキラルおよび非キラルア ミン修飾グラファイト電極を用いアセトフェノンの電解 還元を行なっているが，不斎還元は㧍こらず，むしろ還 元生成物のピナコールに対するカルビノールの生成比に 変化をもたらし，酸性表面で大きく，中性ないしアルカ リ性で小さい結果を得ている。

このように，報告も少ないが，不斉電解合成はまだ良 好な結果が得られるには至っていない.しかし表面を特 異的にデザインした電極の研究が進めば，不斉電解合成 が成功する可能性があろう，

著者らはシクロデキストリン $(\mathrm{CD})$ をグラファイト表 面に化学修飾し，芳香族化合物の位置選択的置換反応を 研究した ${ }^{58 ; 59}$. 図 5 にエステル結合 $(\alpha-\mathrm{CD}$ の第一また は第二テルコールの利用)およびェーテル結合による $\alpha-\mathrm{CD}$ 化学修飾法を示す*3.

CD 存在下, アニソールの次亜塩素酸による化学的反 応は, Breslow らによって行なわれ反応機構が提案され ている ${ }^{60,61)}$.この反応は $\mathrm{Cl}^{-2}$ 支持電解質ア゙ニオンとす る水溶液中で 10 の上うな $\alpha-\mathrm{CD}$ 修飾電極によって同 様に行なうことができる $((6) \sim(8)$ 式).この場合, ゲス ト分子のアニソールは $o$-および $p$-置換配向性存有する が，オルト位は CD の内壁によってブロックされてい

*2（2）式の反応索 edge 面修飾電極で行った場合の 3 の鏡像

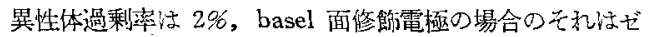
ロであった。

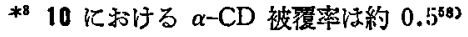
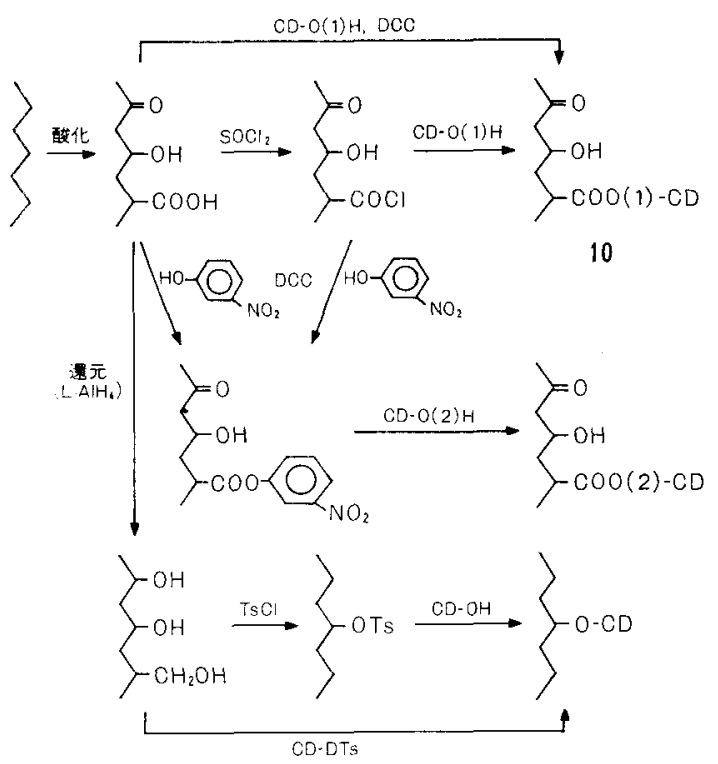

図 5 シクロデキストリン修飾グラフォイト電極の製造 $\mathrm{CD}-\mathrm{OH}:$ シクロデキストリン, DCC : ジシクロへキ シルカルボジイミド， TsCl：トシルクロリト， $-\mathrm{COO}$ (1)-CD : CD の第一フルコールとのエステル, -COO (2)-CD : CD の第二アルコールとのニステル

$$
\text { 然, }
$$

るため，表 1 に示すようなパラ位に選択的塩素化をおこ す.すなわち，未処理のグラファイト電極(東海カーボ ン G 2080）を用いた浸せき直後の電解反応では，ク口

\begin{tabular}{|c|c|c|}
\hline \multirow{2}{*}{ ダラファイト電極の種類 } & \multicolumn{2}{|c|}{$p-10-$ 比 } \\
\hline & 浸せき直後 & 17 日後 \\
\hline 未玑理電極 & 7.1 & 3.5 \\
\hline 酸化処理電極 & 3.5 & 3.5 \\
\hline 還元好理電極 & 4.2 & \\
\hline$\alpha-\mathrm{CD}$ 修飾電極 10 & 17.8 & $>10$ \\
\hline$\alpha$-CD 吸着電㢦 & $>25$ & 5.4 \\
\hline
\end{tabular}
ロアニソールの p-lo 比は 7.1*4 であったが, 10 にお

表 1 各種グラファイト電極に対するアニソールの塩索 化の $p$ - $/ o$-配向比

*4 酶酸中, $25{ }^{\circ} \mathrm{C}$ での塩菜ガスによる化学的塩续化の $p-10$ 比法 3.8 であり, 電気化学的塩菜化では未处理グラフォイ トでも特街が現われている。

*5 $\beta$-CD 吸着電極の塩素化では, アニソールの $\beta$-CD への

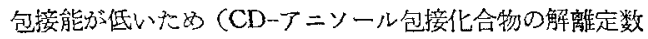
注 $\alpha-\mathrm{CD}$ の場合 $3.7 \times 10^{-8} \mathrm{M}, \beta-\mathrm{CD}$ の場合 $1.9 \times 10^{-2}$ $\mathrm{M})$, バラ位配向性法低下し $p-/ o$-比 $3 \sim 4$ となる ${ }^{39}$. 


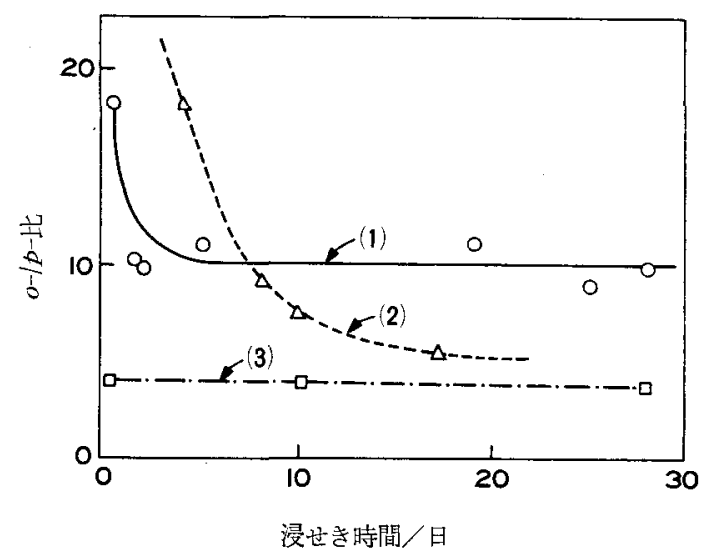

図 6 クロロアニソールの $p-10$-比の浸せき時閒の影響

(1) : $\alpha-\mathrm{CD}$ 修飾グラフォイト電極

(2) $: \alpha-\mathrm{CD}$ 吸着グラフォイト電極

(3)：酸化処理グラファイト電極

いては 17.8 でパラ位配向性が著しく向上した。 $\alpha$-CD 吸着電極を用いた浸せき直後の反応 ${ }^{* 5}$ は 10 より $p$-/o比が高かったが，17 日間蒸留水に浸せき後には之の值 は逆転した，同一電極による $p$ - $/ o$-比の経時変化を図 6 に示す.この結果は, 浸せき開始後の比較的短かい日数 で 10 に吸着していた $\alpha-\mathrm{CD}$ は脱着するが，化学修飾 された $\alpha-\mathrm{CD}$ は電解反応に対しても安定であると解䣋 できる。

トルエン，クロロベンゼンの塩素化，アニソールなど の陽極シアノ化反応に対しては 10 の効果はあまり認め られなかった。

アニソールの塩素化に执いては，(8) 式のよらないー CD のオキシクロリドを経由して進行し，しかもその反 応は塩素ガスによる直接的反応より著しく速いため, $a-\mathrm{CD}$ の效果が認められたものと考えられる。このよう に，現状では CD 修飾電極を用いて一般的にパラ位選 択的な反応を行ならには至っていない，

$\mathrm{CD}$ 修飾電極の別の利用梳酸化還元電位に差のない混 合物に対して，その一つを選択的に電解反応できること にある ${ }^{62,63)}$. たとえば， 0 一と p-ニトロフェノールの混 合物の一方の選択的還元は, 水溶液, グラッシーカーボ ン電極でそれぞれの還元電位が -0.7 およ゙ $-0.8 \mathrm{~V}$ vs. SCE と近いため容易でない. しかしパラ体の $\alpha-\mathrm{CD}$ への包接能はオルト体のそれより約 10 倍大きく ${ }^{64}, \alpha-$ $\mathrm{CD}$ に包接された反応基質は $\alpha-\mathrm{CD}$ の内壁の塩基性場 のために還元電位が負側にシフトすることになる，した がって 10 岂用い $-0.70 \mathrm{~V}$ vs. SCE で電解すると, オ

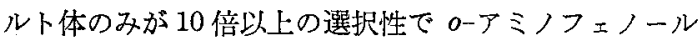
に還元される ${ }^{62)}$.

またこの手法はひとつの反応基質に存在するいくつ 汃の電気化学的活性基の5ちの特定の基のみ選択的に
反応させることにも到用できるであろら。

最後に, 文献 $2,3,11$ 以外の化学修飾電極関係の総説 をあげておく 65 な69)

\section{文献}

1) B.F. Watkins, J.R. Behling, E. Kariv and L.L. Miller, J. Amer. Chem. Soc. 97, 3549 (1975).

2) 藤平正道, 長 哲郎, 電気化学 45, 270 (1977).

3) 藤平正道, 長 哲郎, ぶえせき 1978， 495.

4) J.F. Evans and T. Kuwana, Anal. Chem. 49, 1632 (1977).

5) M. Fujihira, A. Tamura and T. Osa, Chem. Lett. 1977, 361 .

6) S. Mazur, T. Matusinovic and K. Cammann, $J$. Amer. Chem. Soc. 99, 3888 (1977).

7) R. Nowak, F.A. Schultz, M. Umaña, H. Abruna and R.W. Murray, J. Electroanal. Chem. 94, 219 (1978).

8) N. Oyama, A.F. Brown and F.C. Anson, J. Electroanal. Chem. 87, 435 (1978); 88, 289 (1978).

9) J.M. Thomas, E.L. Evans, M. Barber and P. Swift, Trans. Faraday Soc. 67, 1875 (1971).

10) B.E. Firth, L.L. Miller, M. Mitani, T. Rogers, J. Lennox and R.W. Murray, J. Amer. Chem. Soc. 98, 8271 (1976).

11）藤平正道，長 框郎，電気通信学会信学技報 $\mathrm{ED} 78-12$, 19 (1978).

12) P.R. Moses, L. Wier and R.W. Murray, Anal. Chem. 47, 1882 (1975).

13) T. Osa and M. Fujihira, Nuture (London) 264, 349 (1976).

14) P.R. Moses and R.W. Murray, J. Amer. Chem. Soc. 98, 7435 (1976).

15) P.R. Moses, L.TW. Wier, J.C. Lennox, H.O. Finklea, J.R. Lenhand and R.W. Murray, Anal. Chem. 50, 576 (1978).

16) H.O. Finklea and R.W. Murray, J. Phys. Chem. 83, 353 (1979).

17) D.F. Smith, K. Willman, K. Kuo and R.W. Murray, J. Electroanal. Chem. 95, 217 (1979).

18) P.R. Moses and R.W. Murray, J. Electroanal. Chem. 71, 393 (1977).

19) J.R. Lenhard, R. Rocklin, H. Abruña, K. Wallman, K. Kuo, R. Nowak and R.W. Murray, J. Amer. Chem. Soc. 100, 5213 (1978).

20) J.R. Lenhard and R.W. Murray, J. Electroanal. Chem. 78, 195 (1977).

21) M.S. Wrighton, M.C. Palazzotto, A.B. Bocarsly, J.M. Bolts, A.B. Fischer and L. Nadjo, J. Amer. Chem. Soc. 100, 7264 (1978).

22) A.B. Fischer, N..S. Wrighton, M. Umaña and R.W. Murray, J. Amer. Chem. Soc. 101, 3442 (1979).

23) M.S. Wrighton, R.G. Austin A.B. Bocarsly, J.M. Bolts, O. Haas, K.D. Legg, L. Nadjo and M.C. Palazzotto, J. Amer. Chem. Soc, 100, 1602 (1978).

24) J.M. Bolts, A.B. Bacarsly, M.C. Palazzotto, E.G. Walton, N.S. Lewis and M.S. Wrighton, J. Amer. Chem. Soc. 101, 1378 (1979).

25) J.M. Bolts and M.S. Wrighton, J. Amer. Chem. Soc. 100, 5257 (1978).

26) M. Fujihira, N. Ohishi and T. Osa, Nature (London) 268, 226 (1977). 
27) M. Fujihira, T. Kubota and T.Osa, J. Electroanal. Chem. 119, 379 (1981).

28) J. Janata, J. Amer. Chem. Soc. 97, 2914 (1975).

29) L.L. Miller and M.R. Van de Mark, J. Amer. Chem. Soc. 100, 639 (1978); J. Electroanal. Chem. 88, 437 (1978).

30) M.R. Van de Mark and L.L. Miller, J. Amer. Chem. Soc. 100, 3223 (1978).

31) N. Oyama and F.C. Anson, J. Amer. Chem. Soc. 101, 739 (1979).

32) H. Tachikawa and L.R. Faulkner, J. Amer. Chem. Soc. 100, 4379, 8025 (1978).

33) A. Merz and A.J. Bard, J. Amer. Chem. Soc. 100, 3222 (1978).

34) F. Bruno, M.C. Pham and J.E. Dubois, J. Electroanal. Chem. 86, 147 (1978); 99, 331 (1979).

35) K. Itaya and A.J. Bard, Anal. Chem. 50, 1487 (1978).

36) M.C. Pham, P.C. Lacaze and J.E. Dubois, J. Electroanal. Chem. 86, 147 (1978); 99, 331 (1979).

37) K. Doblhofer, D. Nölte and J. Ulstrup, Ber. Bun senges. Phys. Chem. 82, 403 (1978).

38) J.R. Lenhard and R.W. Murray, J. Amer. Chem. Soc. 100, 7870 (1978).

39) M.S. Wrighton, R.G. Austin, A.B. Bocarsly, J.M. Bolts, O. Haas, K.D. Legg, L. Nadjo and M.C. Palazzotto, J. Electroanal. Chem. 94, 219 (1978).

40) A. Kozawa, V.E. Zilionis and R.J. Brodd, J. Electrochem. Soc. 117, 1470 (1970); 118, 1705 (1971).

41) R.F. Lane and A.T. Hubbard, J. Phys. Chem. 79, 808 (1975).

42) A.P. Brown, C. Koval and F.C. Anson, J. Electroanal. Chem. 72, 379 (1976).

43) A.P. Brown and F.C. Anson: Anal. Chem. 49, 1589 (1977).

44) M.S. Wrighton, R.G. Austin, A.B. Bocarsly, J.M. Bolts, O. Haas, K.D. Legg, L. Nadjo and M.C. Palazzotto, J. Electroanal. Chem. 87, 429 (1978).

45) M. Fujihira and T. Osa, 未発表.

46) R.F. Lane and T. Hubbard, J. Phys. Chem. 77,
1401 (1973).

47) J.C. Lennox and R.W. Murray, J. Amer. Chem. Soc. 100, 3710 (1978).

48) A.P.Brown and F.C. Anson, J. Electroanal. Chem. 92, 133 (1978).

49) J.C. Lennox and R.W. Murray, J. Electroanal. Chem. 78, 395 (1977).

50) A.F. Diaz, J. Amer. Chem. Soc. 99, 5838 (1977).

51) H. Abruña, T.J. Meyer and R.W. Murray, Inorg. Chem. 11, 3233 (1979).

52) N. Oyama and F.C. Anson, J. Amer. Chem. Soc. 101, 1634 (1979).

53) M. Sharp, Electrochim. Acta 23, 287 (1978).

54) N. Kobayashi, M. Fujihira and T. Osa, 未発表.

55) O.C. Tse and T. Kuwana, Anal. Chem. 50, 1315 (1978).

56) B.E. Firth and L.L. Miller, J. Amer. Chem. Soc. 98, 8272 (1976).

57) L. Horner and W. Brich, Justus Liebigs Ann. Chem. 1978, 1354

58) T. Matsue, M. Fujihira and T. Osa, J. Electrochem. Soc. 126, 500 (1979); 128, No. 7 (1981) in press.

59) T. Matsue, M. Fujihira and T. Osa, Bull. Chem. Soc. Japan 52, 3692 (1979).

60) R. Breslow and P. Campbell, J. Amer. Chem. Soc. 91, 3085 (1969).

61) R. Breslow, H. Kohn and B. Siegel, Tetrahedron Lett. 1976, 1645.

62) 末永智一, 学位論文 (1981年 東北大学).

63) T. Matsue, M. Fujihira and T. Osa, Anal. Chem. 53, 722 (1981).

64) T. Osa, T. Matsue and M. Fujihira, Heterocycles 6, 1833 (1977).

65）藤平正道，長 哲郎，化学工業 28，922 (1977).

66) 長 哲郎, 化学 34, 534 (1979).

67) R.W. Murray, Acc. Chem. Res. 13, 135 (1980).

68) 藤平正道, 長 哲郎, 化学工業 31, 697 (1980).

69) 長 哲郎, 藤平正道, 化学增刊 86, p. 8 (1980), 化学同 人.

\section{電気化学工業と電力貯蔵方式 調查報告軎}

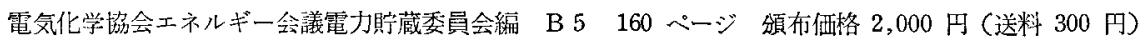

本報告書は，エネルギ一問题の重要性:に鑑み，電気化学工業に扔いて多面的に省資源・省エネルギ一対応を図ると共に，電気事業 にとっても極めて有効な方策の一つとして共通な課題である電力貯蔵方式について行った調査報告書です.

<内 容> $\bigcirc$ 内 容 $\bigcirc$ 電気事業の現状 $\bigcirc$ 電気化学工業の現状 $\bigcirc 2$ 次電池による電力貯蔵 $\bigcirc$ 電力貯蔵用新型常温電池

○然料電池による発電 ○水電解一燃料電池の組合せによる電力貯蔵 ○総 括

（申込先 100 東京都干代田区有楽町 1-12-1 新有楽町ビル 電気化学協会・祭03-214-6001) 